\title{
Use of Interactive Media In Biochemical Material
}

\author{
Puji Kurniawati ${ }^{a, *}$, Reni Banowati ${ }^{a}$ \\ ${ }^{a}$ Diploma of Analytical Chemistry, Islamic University of Indonesia \\ *Corresponding author:puji_kurniawati@uii.ac.id
}

\begin{abstract}
A study of the use of interactive media in Biochemistry materials at Chemical Analysis Department, Islamic University of Indonesia has been done. Interactive media used in this research is animation media based on molymod and Flash. Molymod is used in lecturing activities to explain the macromolecular bonds and structures that are the focus of the Biochemistry course while the Flash-based animation is expected to improve students' understanding of biochemical metabolism processes in the body. The purpose of this study is to increase students' interest in biochemical learning which is known to be difficult and unattractive. Stages of this research there are 6, namely the initial stage, pre-design, design, model evaluation, field application and evaluation of results. The initial stage is done by improving the Course Outline (CO) and Teaching Unit Course (SAP) as well as the creation of lecture modules. Contents, materials and display modules have been reviewed by incorporating elements of analysis of biochemical examples that are often performed in the industrial world. Molymod of small capacity per set can only make two interconnected monomers. Flash-based animation media can be used during college or can be opened by students independently. The use of interactive media can stimulate students' high interest and understanding, i.e. $74.38 \%$ and $72.88 \%$ respectively. The correlation relationship between understanding and interest is also high which is marked with correlation coefficient value 0.806 . The achievement of value $\geq \mathrm{B}$ / C obtained with interactive media equal to $76,57 \%$ and Lecturer Performance Value (NKD) equal to 3.56 .
\end{abstract}

Keywords: interactive media, molymod, biochemistry

\section{INTRODUCTION}

Learning can be interpreted as a process of activity that makes cognitive and motor changes through interaction. Learning can also be interpreted as a process of behavior change. In terms of psychology, various aspects either directly or indirectly arising from the students cause individual differences. As for those aspects, namely; cognitive (knowledge), affective (ability), and psychomotor (skills), not to forget also includes intelligence, interest, talent and socioeconomic conditions. Technological advances make people intentionally or unintentionally have and will interact with technology. Electronic media as a result of technological developments gained a considerable place and attention for the learners and a great influence on the development of education.

The benefits of activity in learning caused by the progress of science and technology are that learners can find their own and directly experience the learning process. Learning is meant in the form of learning that is implemented in realistic and concrete, so develop understanding and critical thinking and avoid the occurrence of persistent verbalism. Submission of non-varied teaching materials may be the cause of non-achievement of desired course objectives. With the variation in lectures, students are expected to be able to do their own that will ultimately understand the context and contents of the courses presented.

Benefits of Interactive Learning Media is expected to motivate students to learn independently, creatively, effectively and efficiently. In addition to this interactive animated media, is expected to reduce student boredom because during this lecture process is done face-to-face method (lecture). Learning media is one of the components supporting the success of teaching and learning process. According to RI Law No.20 Year 2003 Article 1 paragraph 20: Learning is the process of interaction of learners with educators and learning resources in a learning environment [1].

Biochemistry is a compulsory course that must be taken by students in the fourth semester in Diploma of Analytical Chemistry FMIPA UII. This course contains the chemical reaction mechanism of macromolecule compounds in the human body. By following this course is expected to Chemical Analysis 
students can understand the biochemical mechanism so that it can be applied in the analysis of biochemical compounds in the laboratory. The weight of this course is only 2 credits while the material must be taught so much that the biochemical material taught for students of Chemical Analysis only revolves around carbohydrates, proteins and lipids and metabolism in the body. Previous biochemical courses have the following disadvantages:

1. Lecturing less interesting

The content of the Biochemistry course is its macromolecules and experience in the body. The macromolecules studied are fat protein carbohydrates and DNA-RNA. The three-dimensional shape of the constituent or monomer of these macromolecules is very important in the metabolic processes in the body. It is very difficult for students to understand the shape of three-dimensional monomer structures because the medium used so far is a one-dimensional medium. In addition, the cycle of macromolecular metabolism is a very complicated stage for a less interesting class.

2. Unavailability of module

Reference biochemistry courses can be found easily and quite a lot. However, a good book reference is usually a foreign language book. Students are less interested if they have to use a reference book that uses a foreign language. This causes students have difficulty in translating reference books and rely solely on the power point material provided by the lecturer.

3. The props are not yet available to standard

One of the objectives of this course is for students to conduct analysis in the field of biochemistry. For reliable technical information in biochemistry, courses are always inserted with biochemical analysis methods. Lack of teaching aids makes students less able to understand the principles of biochemical analysis.

Based on the above description it is necessary an improvement effort that will be done to support competent performance in accordance with SKKNI Sector Laboratory. One of the lesson strategies that will be developed to provide solutions on strengthening student competence with the advantages of backgrounds that have been arranged above it will be the application of interactive media on Biochemistry course. Interactive Media Usage is expected to motivate students to learn creative independently effectively and efficiently. In addition, with Interactive Media is expected to reduce student boredom because during this learning process is done face-to-face method (lecture).

Aids or instructional media are created and can be used according to the subject and urgency of the course. The subject of a memorizing or theoretical course in the transfer may be enough to use a manual. Different than the learning who needs additional information. In the course, in visualizing a basic burden material caused by the limitations of teachers, tools, tools, materials, costs and so on where the process of delivering information or transfer of knowledge is not enough just by verbal delivery (lecture).

\section{LITERATURE REVIEW}

Interactive multimedia is a combination of media. Based on Hofstetter, understanding interactive multimedia is the utilization of computer to send moving graphic image audio texts (video and animation) into one unit with appropriate links and tools to enable multimedia to perform interactive navigation to create and communicate [2].

In the manufacture of interactive multimedia systems that are devoted to learning the appearance of a system is necessary. A very important view. The screen design is structured to support the desired learning activities. The form of display in a way that can provide information or knowledge for users in teaching and learning activities. Things to note in the screen design:

a. Creating an abstract idea becomes more concrete to make it easier for users to understand the material.

b. The program created is expected to provide material so that it can remain in the memory of the user.

c. Calculation the period of user attention so as not to feel saturated.

d. For each session / different stages are expected to be able to present the different forms of appearance to be attractive to users[3].

As one component of the learning system, the selection and use of multimedia learning should consider the characteristics of other components such as the objectives of the strategy materials and also the evaluation of learning. The characteristics of multimedia learning are:

a. It has more than one converging medium such as combining audio and visual elements.

b. Interactive that has the ability to accommodate user responses 
c. Self-contained in terms of providing comfort and completeness of the content so that users can use it without the guidance of others[4].

\section{RESEARCH METHODS}

The design of the activity on the use of interactive media in Biochemistry courses can be seen in Figure 1. The media used in this course is the procurement of Biochemistry course modules as one of the references, interactive animation media as a presentation advocate during lectures and molymod as a three-dimensional model of macromolecules that will see in Biochemistry courses.

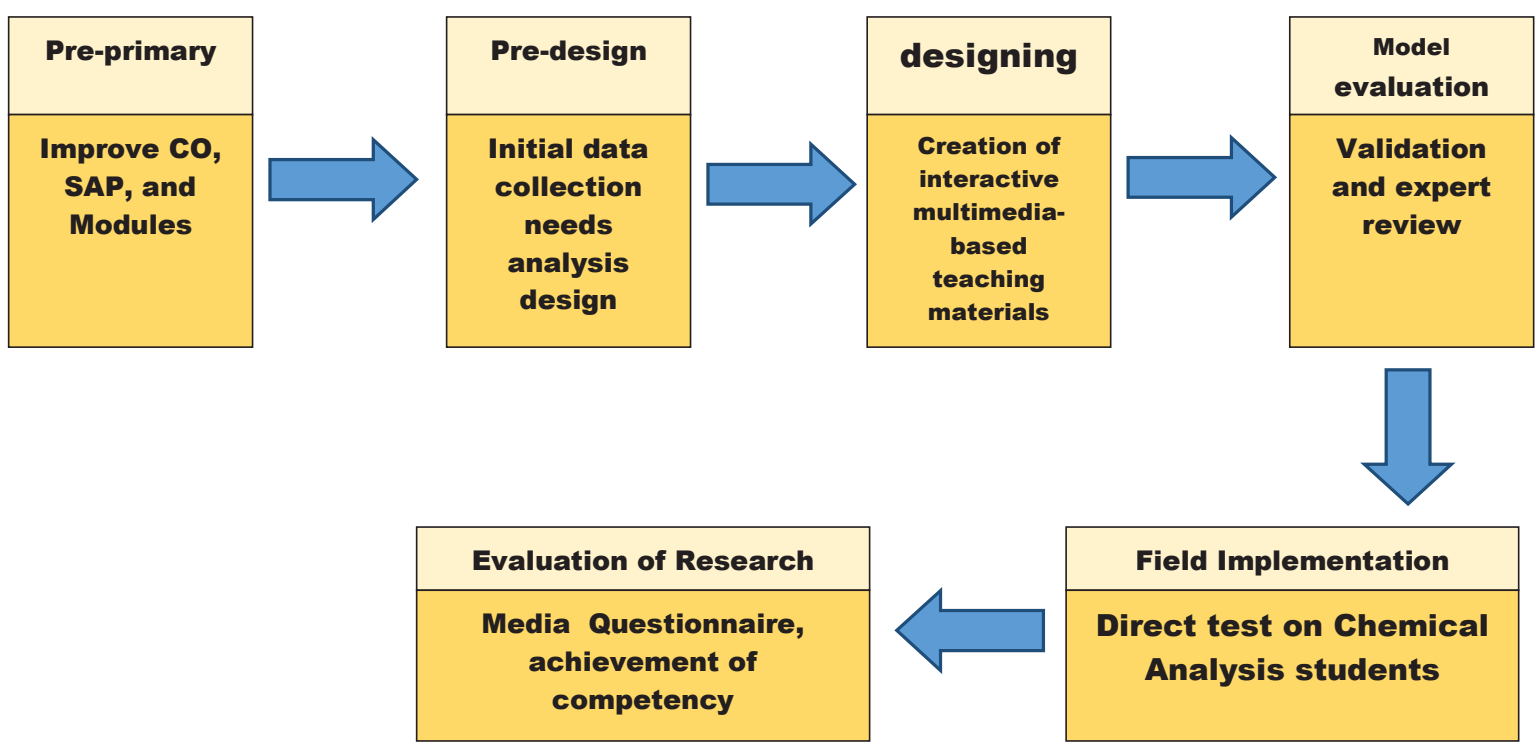

FIGURE 1.The Design of Interactive Media Usage in Biochemistry Course

\section{RESULT AND DISCUSSION}

The results of research using the interactive media in Biochemistry courses can be seen in Table 1. Interactive media used in this research is flash animation media and molymod.

TABLE 1.Result of research by using interactive media in biochemistry course

\begin{tabular}{cllll}
\hline No & \multicolumn{1}{c}{ Parameter } & Baseline & Target & Results \\
\hline 1 & Value is more or equal to B / C & $87,14 \%$ & $90 \%$ & $76,57 \%$ \\
2 & The value of teaching performance of lecturers & 3,67 & 3,75 & 3,56 \\
& (NKMD) & & & $72,88 \%$ \\
3 & Results of the understanding questionnaire & & $74,38 \%$ \\
4 & Results of interest questionnaires & & 0,806 \\
5 & $\begin{array}{l}\text { The correlation coefficient of understanding and } \\
\text { interest }\end{array}$ & & \\
\hline
\end{tabular}

This research's initial objective is to provide a new atmosphere for students so as to create a better learning atmosphere. The condition is expected to increase students' understanding of biochemical materials and will be able to increase their value. Initial stages of this research are the renewal of Lecture Event (SAP) with the application of interactive media in the form of molymod and multimedia. Learning strategy is done in a way that is not monotonous so as to increase student interest in Biochemistry course. The formation of a small group of discussions discussing the analysis of biochemical examples can provide input and open the students' repertoire of biochemical analyzes that are often performed in the industry. 
The availability of module is very helpful for students to use as an alternative reference in Biochemistry courses. The module used in this study has been peeled by the reviewer by providing input related to the content of the material and the overall appearance. The module comes with some examples of qualitative and quantitative analysis with a biochemical sample basis. The module review shows a systematic sequence, using an easy-to-understand language, containing images and chemical structures and explanations [5].

Explanations of biomolecules such as carbohydrates, proteins, and lipids can be done using molymod as the medium. The use of molymod can help the students to understand the macromolecule-forming bonds and chemical structures that are formed. Molymod also provides a three-dimensional picture of the chemical structure of biomolecules. However, the molymod used must be numerous because the biomolecule is a macromolecule consisting of many atoms and chemical bonds [6].

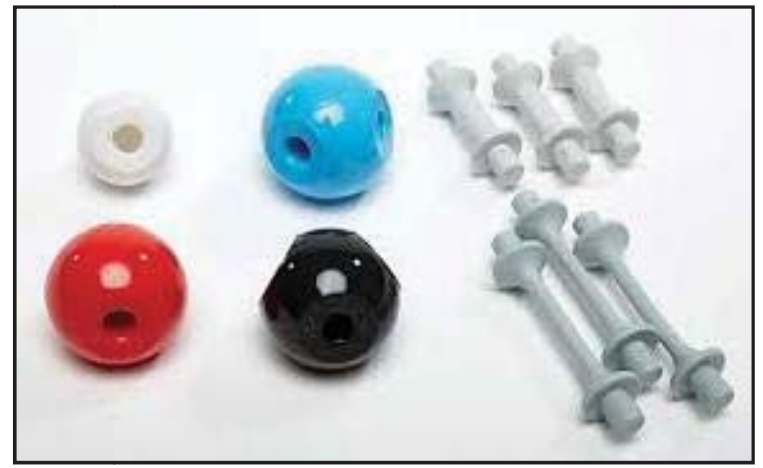

FIGURE 2. Molymod

Interactive animation media is also used in this research by using the flash program [7]. This media is very useful to be able to explain the process metabolism per stage with more clearly. The metabolic cycle can be easily explained with this medium compared to using only regular cycle drawings. In general, this media can attract students and have made the atmosphere more interesting lectures [8,9].

Results of questionnaires to students showed the use of interactive media in the biochemistry course can increase their understanding and interest in learning each of $72.88 \%$ and $74.38 \%$. Based on these figures can be explained the use of interactive media can help students in improving their understanding of biochemical materials. The use of interactive media is also proven to have increased student interest in the subject matter biochemistry is quite difficult and a lot of coverage [10].

The result of evaluation of interest and understanding also shows the existence of a very linear and strong. Where the increase in interest is also offset by an increase in student understanding of the subject matter in the biochemistry course. The correlation between the two components of observation has a strong relationship with the correlation coefficient of 0.806 and standard error 2.514 .

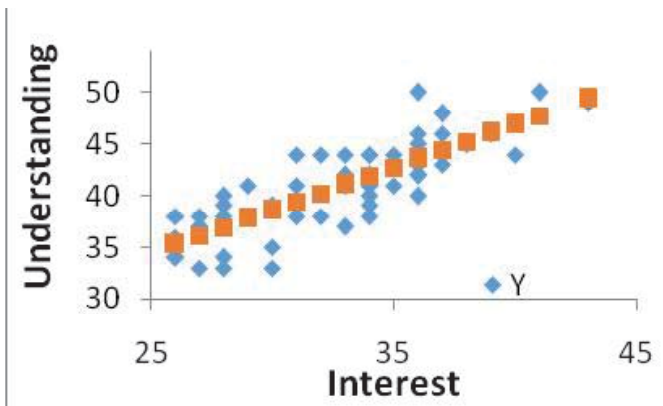

FIGURE 3. Relationship between interest and understanding

The use of interactive media cannot raise the percentage of acquisition value more or equal to $\mathrm{B} / \mathrm{C}$. There is a decrease in the percentage of acquisition more or equal to B / C from academic year $2014 / 2015$ with academic year 2015/2016. In the academic year 2014/2015, the percentage of $\geq B$ / C 
value is $87.14 \%$ and decreased in the academic year $2015 / 2016$ to $76.56 \%$. The decrease in the acquisition value $\geq B$ / C is quite large by reaching a value of $12.14 \%$. This may happen because the student population used is not the same where the average academic ability of the two populations is not the same and very heterogeneous. However, the lecture atmosphere built with the use of interactive media greatly affects the passing rate of $96 \%$.

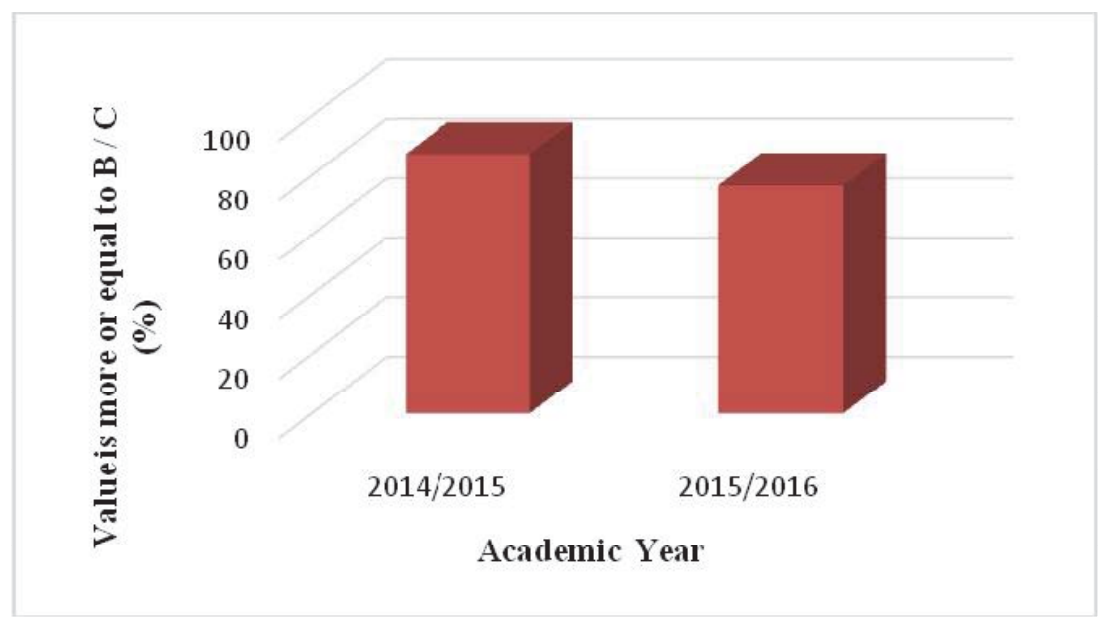

FIGURE 4. Obtaining value $\geq \mathrm{B} / \mathrm{C}$

The value of teaching performance (NKMD) in the two academic year periods can also be used in the academic year 2014/2015 and 2015/2016 respectively are 3.67 and 3.56 with the maximum scale 4 . The acquisition of NKMD in addition to the submission of test questions and final grades of student questionnaires given to students. The result of NKMD in the biochemistry course can be seen in Figure 5

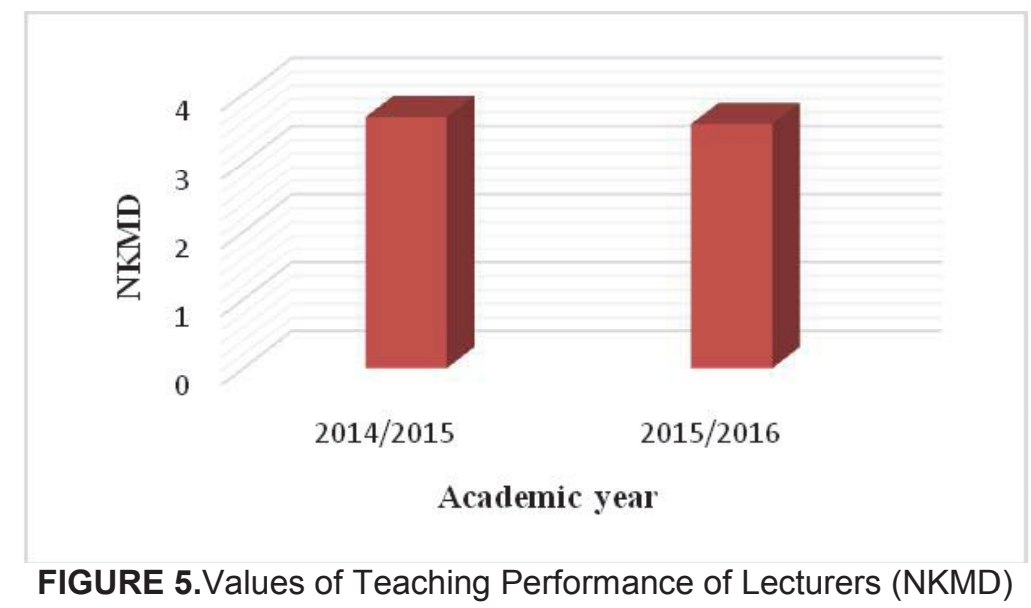

\section{CONCLUSION}

The conclusion can be taken from this research is the use of interactive media in the biochemistry course can increase the understanding and interest of the students respectively $72.88 \%$ and $74.38 \%$. There is a strong correlation relationship between interest and understanding with a corrcorrelation coefficient of 0.806 . The use of interactive mededia can bring the classroom atmosphere so that studstudents are easier to understand the taught biochemical $\mathrm{m}$ material.

\section{ACKNOWLEDGMENTS}

This research was conducted with the support of BPA UII teaching grant. 


\section{REFERENCES}

1. Undang-Undang Republik Indonesia Nomor 20 Tahun 2003 tentang Sistem Pendidikan Nasional. Jakarta: Kemenristek Dikti.T. Kartini, JPD, 8, 2017.

2. A. Ginanjar, "Pengembangan Media Pembelajaran Modul Interaktif Mata Kuliah Pemindahan Tanah Mekanik," thesis, Universitas Sebelas Maret, 2010.

3. S. Winardi, and S. Belo, Link, 16,1, 11-18 (2012).

4. S. Prasetyo, "Pengembangan Pembelajaran Dengan Menggunakan Multimedia Interaktif Untuk Pembelajaran Yang Berkualitas," thesis, Universitas Negeri Semarang, 2007.

5. W. S. Bradshaw, K. J Groneman, J. Nelson and J. D. Bells, Biochem. Mol. Biol. Educ. 46, 1, 7-23 (2018)

6. C. Trujillo, M. M. Copper, and M. W. Klymkowsky, Biochem. Mol. Biol. Educ. 40, 100-107 (2012)

7. M. Harle and M. H. Towns, Biochem. Mol. Biol. Educ. 41, 369-376 (2013)

8. B. G. Ooi, and M.J Sanger, J Chem Educ, 86, 4, 454-455 (2009)

9. S. M. Barclay, M.N Jeffres, and R. Bhakta, Am. J. Pharm. Educ. 75, 2 (2009)

10. M. J Costa, Biochem. Mol. Biol. Educ. 41, 110-111 (2013) 